\title{
SIFAT ANTIMIKROBA KOMBINASI SENYAWA KIMIA ANTARA EKSTRAK DAUN LIDAH BUAYA (Aloe vera L) DENGAN DAUN SIRIH (Piper bettle L) TERHADAP BAKTERI STREPTOCOCUS MUTANS PENYEBAB DENTAL PLAK
}

I Gusti Agung Ayu Putu Swastini ${ }^{1}$, I Gusti Agung Ayu Dharmawati ${ }^{2}$, I Gede Surya Kencana ${ }^{3}$, Ni Made

Sirat $^{4}$

1,2,3,4 Politeknik Kesehatan Denpasar Jurusan Kesehatan Gigi

Koresponden : I Gusti Agung Ayu Putu Swastini/agungswastini18@gmail.com

\begin{abstract}
Background: Plants that are medical and used for generations are aloe vera and betel leaf, which contain natural chemical and have antimicrobial and antiseptic properties.

Objective: The purpose of this study was to calculate the growth inhibition zone of Streptococcus mutans by using the interaction of aloe vera extract and betel leaf, with a concentration of $50 \%$, $75 \%, 100 \%$.
\end{abstract}

Method: This research was carried out at the Microbiology Laboratory of Udayana University using a pure experimental method of extracts of Aloe vera leaves and betel leaves with concentrations of 50\%, 75\%, 100\%, seven repetitions, using Streptococcus mutans ATCC 35668, and isolation media for Mueller Hilton plus $5 \%$ goat blood.

Results: The average inhibition zone diameter in the interaction groups of aloe vera extract and betel leaf in each group was statistically significant difference $(\mathrm{p}<0.05)$, where the inhibitory concentration with the highest $100 \%$ concentration was an average of $82.6 \mathrm{~mm}$ with very strong criteria.

Conclusion: The interaction of aloe vera leaf extract and betel leaf with a concentration of $100 \%$ has the highest inhibitory power of $82.6 \mathrm{~mm}$, with very strong criteria.

Keywords: Aloe vera leaf extract, betel leaf extract, antibacterial, inhibitory zone.

\begin{abstract}
Abstrak
Background: Tanaman yang bermanfaat sebagai obat dan digunakan secara turun temurun adalah lidah buaya dan daun sirih, yang mengandung zat kimia alami dan mempunyai sifat antimikroba dan antiseptik.

Tujuan: Tujuan penelitian ini adalah untuk menghitung zona hambat pertumbuhan Streptokokus mutans dengan menggunakan interaksi ekstrak lidah buaya dan daun sirih, dengan konsentrasi 50\%, $75 \%, 100 \%$.

Methode: Penelitian ini dilaksanakan di Laboratorium Mikrobiologi UNUD menggunakan metode eksperimental murni ekstrak daun lidah buaya dan daun sirih dengan konsentrsi 50\%, 75\%, 100\%, tujuh kali pengulangan, menggunakan bakteri Streptococcus mutans ATCC 35668, dan media isolasi agar Mueller Hinton ditambah 5\% darah kambing.

Hasil: Rata-rata diameter zona hambat pada group interaksi ekstrak lidah buaya dan daun sirih tiap grup perbedaannya secara statistic adalah signifikan, $(\mathrm{p}<0,05)$, dimana daya hambat dengan konsentrasi $100 \%$ paling tinggi sebesar rata-rata $82,6 \mathrm{~mm}$ dengan kriteria sangat kuat.

Kesimpulan: Interaksi ekstrak daun lidah buaya dan daun sirih dengan konsentrasi $100 \%$ memiliki daya hambat paling tinggi yaitu sebesar $82,6 \mathrm{~mm}$, dengan criteria sangat kuat.
\end{abstract}

Keywords: Ekstrak daun lidah buaya, ekstrak daun sirih, antibakteri, zona hambat. 
JURNAL KESEHATAN GIGI

(Dental Health Journal)

Vol. 7 No.2 Agustus 2020

\section{Pendahuluan}

Plak gigi adalah biofilm yang menempel pada permukaan gigi, restorasi, dan peralatan prostetik (termasuk gigi palsu dan jembatan) jika dibiarkan tidak terganggu. Memahami pembentukan, komposisi, dan karakteristik plak membantu mengendalikannya ${ }^{1}$. Pelikel yang didapat adalah lapisan saliva yang sebagian besar terdiri dari glikoprotein dan terbentuk segera setelah pembersihan gigi atau pajanan gigi baru, bakteri kemudian menempel pada lapisan pelikel, membentuk koloni mikro, dan matang pada gigi, yang dapat menyebabkan penyakit mulut ${ }^{2}$.

Sebagian besar mikroorganisme yang membentuk biofilm adalah Streptococcusmutans dan anaerob lainnya, meskipun komposisi yang tepat bervariasi berdasarkan lokasi di mulut. Contoh-contoh anaerob tersebut termasuk fusobacterium dan actinobacteria $^{3}$. S. mutans dan anaerob lainnya adalah penjajah awal permukaan gigi, dan memainkan peran utama dalam pembentukan komunitas biofilm awal. Semua mikroorganisme ini muncul secara alami di dalam rongga mulut dan biasanya tidak berbahaya. Namun, kegagalan untuk menghilangkan plak dengan menyikat gigi secara teratur memungkinkan mereka untuk berkembang biak tanpa diperiksa dan dengan demikian menumpuk di lapisan yang tebal, yang berdasarkan metabolisme biasa mereka dapat menyebabkan berbagai penyakit gigi untuk inang. Mikroorganisme yang terdekat dengan permukaan gigi biasanya mendapatkan energi dengan memfermentasi sukrosa makanan; selama fermentasi mereka mulai menghasilkan asam ${ }^{4}$.

Lidah buaya (Aloevera), mempunyai beberapa kandungan Lignin, Saponin, anthraqurnonealoin, barbaloin, isobarbaloin, anthrax nol, aloeemodin, anthracenesinamat, asamkrisophanat, eteraloinresistanol. Sehingga lidah buaya (Aloe vera) digolongkan sebagai pengobatan seperti antibiotik, antiseptik dan anti bakteri.
Tanaman ini bermanfaat sebagai bahan baku,industry farmasi dan kosmetik, serta sebagai bahan baku makanan dan minuman kesehatan, obat-obatan yang tidak mengandung bahan pengawet kimia.

Salah satu tanaman yang bermanfaat sebagai obat yang digunakan secara turunmenurun untuk menyembuhkan luka yaitu sirih (Piper betle L.). Daun sirih digunakan sebagai obat batuk, obat cacing, dan antiseptik pada luka ${ }^{6}$. Pemanfaatan sirih dalam pengobatan tradisional disebabkan adanya sejumlah zat kimia atau alami yang mempunyai aktivitas antimikroba. Ekstrak sirih hijau mampu membunuh bakteri Streptococcus mutans dan karena di dalamnya terkandung bahan kimia yang mempunyai aktivitas anti bakteri yaitu: minyak atsiri, tanin, flavonoid, dan saponin. Lidah buaya (Aloe vera L.) juga merupakan tanaman yang telah lama digunakan untuk pengobatan. Secara tradisional lidah buaya telah digunakan sebagai obat secara tersendiri atau dicampur dengan bahan lain?

\section{Material and Methods}

\section{Materials}

Penelitian ini merupakan penelitian eksperimental dengan rancangan completely rendomized posttest only control group design. Penelitian ini dilaksanakan di Laboratorium Mikrobiologi Universitas Udayana. Bakteri streptokokus mutans, dengan bahan ekstrak daun lidah buaya dan daun sirih, TSH untuk refres bakteri, Etanol 96\%, $\mathrm{NaOCl} 0,9 \%$, Sarbitol Broth, Voges Proskauer.

\section{Methods}

Pembuatan ekstrak lidah buaya dan daun sirih, kemudian dikeringkan dan diblender, untuk dimaserasi dengan $500 \mathrm{ml}$ etanol pro analisis suhu kamar 72 jam. Filtrat yang diperoleh melalui penyaringan diuapkan dengan vacuum rotary evaporator pada suhu $35^{\circ} \mathrm{C}$ dengan tujuan untuk memisahkan solven 
dan ekstrak, sehingga diperoleh ekstrak kental.

Bakteri streptococcus mutans yang dipakai isolate murni, diperoleh di laboratorium Mikrobiologi Fakultas kedokteran Universitas Udayana. Pembuatan suspense bakteri dilakukan dengan cara mengambil 2-3 koloni dari media TSA denga nose steril, dimasukkan dan dihomogenkan kedalam $4 \mathrm{ml}$ Nutrient Broth (NB) dan diinkubasi pada suhu $37^{\circ}$ selama 24 jam. Susupensi bakteri tersebut kekeruhannya disetarakan dengan standar McFarland 0,5 yang setara dengan $10^{8}$.

Uji daya hambat yang digunakan adalah menggunakan metode Kirby Bauer. Media Mueler Hilton Agar (MHA) ditambah $1 \mathrm{ml}$ suspense biakan bakteri streptococcus mutans pada masing-masing cawan petri dan dihomogenkan dengan cara digoyang secara simultan. Kertas cakram didahkan sebanyak $20 \mu 1$. Ekstrak kulit daun lidah buaya dengan konsentrasi $50 \%$, 75\%, dan $100 \%$, sebagai control dipakai chlorhexidine untuk control positif dan negative, kertas cakram, diletakkan pada media dengan pinset steril dan diinkubasi pada suhu $37^{\circ} \mathrm{C}$ selama 24 jam dengan posisi terbalik. Zona hambat yang dibentuk menunjukkan tingkat kepekaan bakteri uji terhadap bahan anti bakteri tersebut.

\section{Hasil}

Tabel 1. The Width of Streptococcus mutans inhibitory Zone in the Treatment Group

\begin{tabular}{lccc}
\hline Subject Group & $\mathrm{n}$ & $\begin{array}{c}\text { Mean SD } \\
\text { Streptococcus mutans Inhibition Zone } \\
\text { (millimeters) }\end{array}$ & $\mathrm{P}$ \\
\hline Control & 7 & $0 \pm 0,00$ & \\
LBS 50\% & 7 & $0 \pm 18,00$ & 0,001 \\
LBS 75\% & 7 & $0 \pm 51,07$ & \\
LBS 100\% & 7 & $0 \pm 82,86$ & \\
\hline
\end{tabular}

Table 2. The Difference of Streptococcus mutans Inhibitory Zone Between The Treatment Groups

\begin{tabular}{lcccc}
\hline Variabel & Group & Group $(\mathrm{J})$ & Mean Difference (I-J) & $\mathrm{P}$ \\
\cline { 2 - 4 } & Control & $50 \%$ & $-18,00$ & $<0,001$ \\
& & $75 \%$ & $-51,07$ & $<0,001$ \\
& & $100 \%$ & $-82,86$ & $<0,001$ \\
& $50 \%$ & Control & 18,00 & $<0,001$ \\
Ekstrak daun & & $75 \%$ & $-33,07$ & $<0,001$ \\
lidah buaya dan & & $100 \%$ & $-31,79$ & $<0,001$ \\
daun sirih & $75 \%$ & Control & 82,86 & $<0,001$ \\
& & $50 \%$ & 33,07 & $<0,001$ \\
& & $100 \%$ & 31,79 & $<0,001$ \\
& \multirow{2}{*}{$100 \%$} & Control & 82,86 & $<0,001$ \\
& & $50 \%$ & 31,79 & $<0,001$ \\
\hline
\end{tabular}




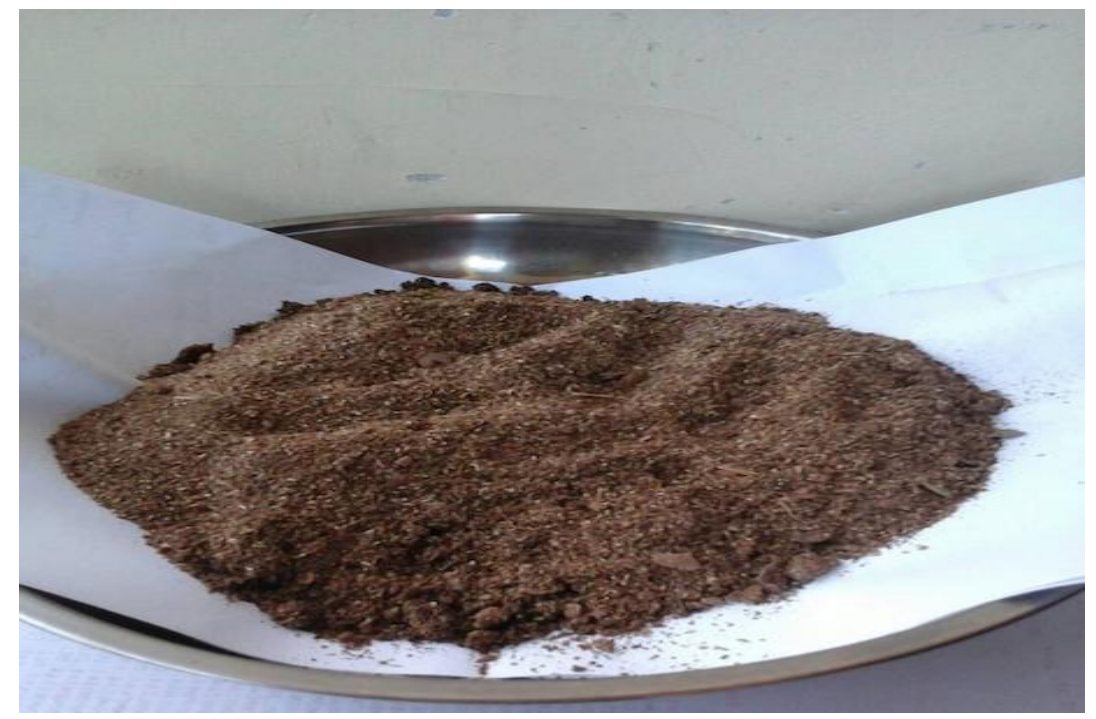

Gambar 1. Ekstrak daun lidah buaya dan daun sirih

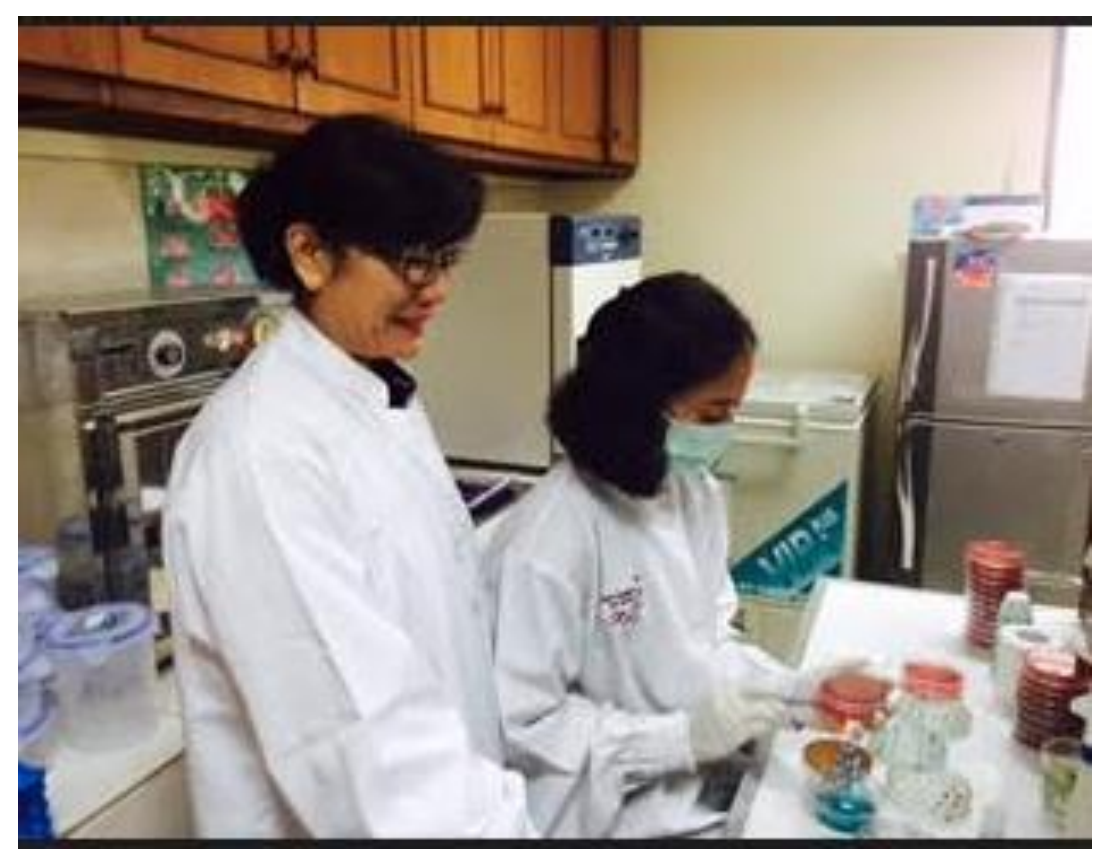

Gambar 2. Proses Laboratorium Reaksi Ekstrak Dengan

Bakteri Untuk Menentukan Daya Hambat 


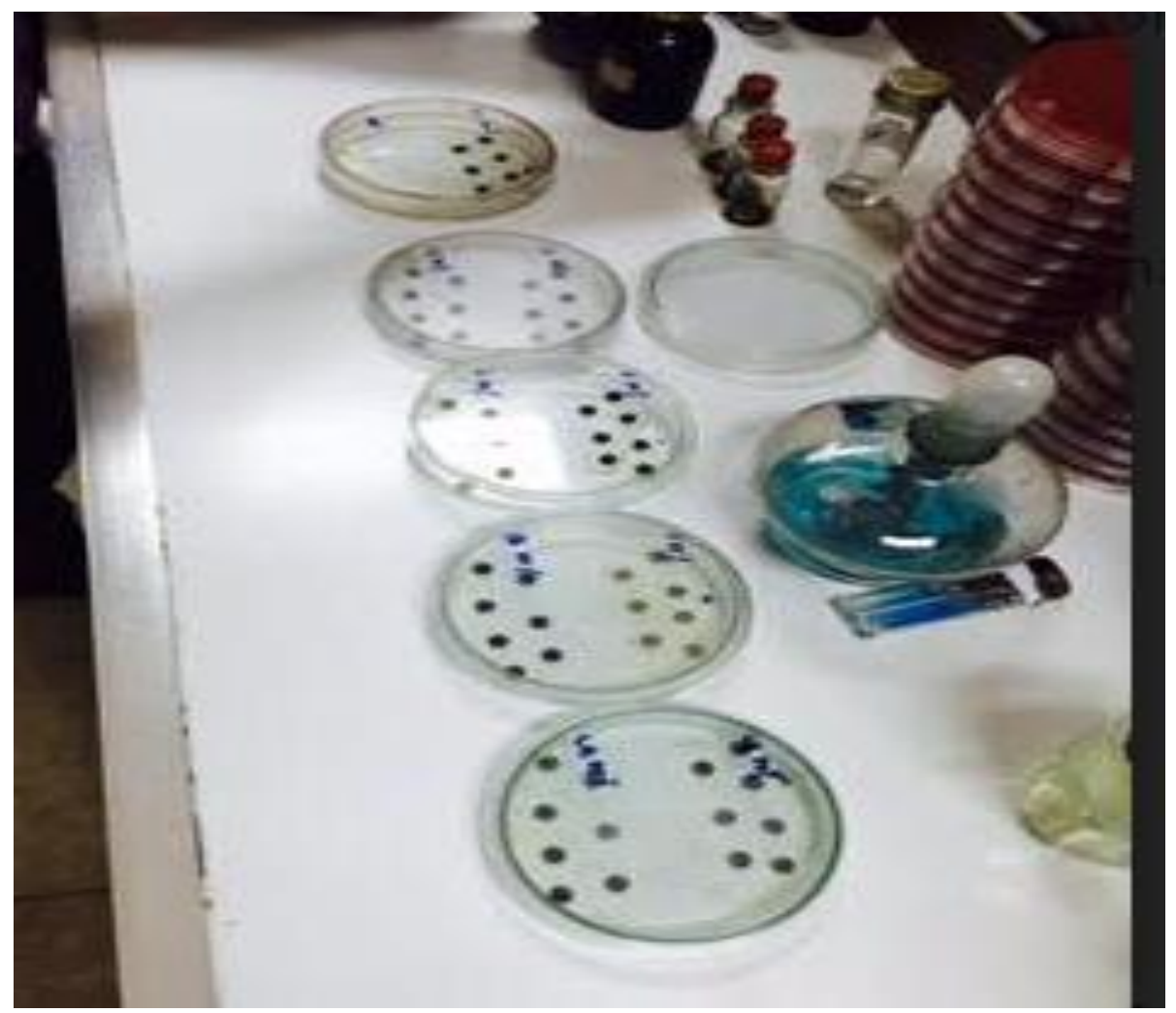

\section{Gambar 3. Daya Hambat Zona Hambat Interaksi Ekstrak Daun Lidah Buaya dan daun Sirih}

\section{Pembahasa}

Pada pengamatan hasil daya hambat kombinasi ekstrak lidah buaya dan daun sirih dengan konsentrasi $50 \%$ dengan daya hambat $18,00 \mathrm{~mm}$ dengan criteria kuat, adalah paling kecil dibandingkan dengan konsentrasi $75 \%$ (51,07), dan $100 \%$ (82,86 mm), dengan criteria sangat kuat.

Hasil uji antibakteri ekstrak daun lidah buaya, daun sirih, dan kombinasi antara kedua ekstrak membentuk daya hambat pada media pertumbuhan yaitu media MHA. Berdasarkan Analisis Varian ekstrak daun lidah buaya dan daun sirih menunjukkan adanya pengaruh yang nyata terhadap daya hambat Streptococcus mutans. Selain itu terdapat juga interaksi antar kedua ekstrak terhadap daya hambat bakteri. Adanya perbedaan yang nyata maka dilanjut kan dengan uji jarak berganda Duncan pada taraf 0,05 untuk melihat perbedaan pada setiap perlakuan seperti terlihat pada Tabel 2 .
Dari hasil penelitian diketahui bahwa daun sirih mampu menghambat pertumbuhan Staphylococcus aureus. Kandungan minyak atsiri, flavonoid, saponin, dan tannin berfungsi sebagai antibakteri. Senyawa kimia dan aktivitas anti bakteri sirih asal Papua mampu menghambat bakteri Gram positif (Staphylococcus aureus, Bacillussubtilis, dan Lysteriamonocytogenes) dan Gramnegatif (Salmonellatyphimurium, Escheriacoli, dan Pseudomonpsedomallaei). Ekstrak tunggal lidah buaya dan ekstrak tunggal daun sirih memiliki daya hambat yang lebih rendah dari pada kombinasi keduanya ${ }^{8}$.

Selain pengaruh terdapat kombinasi antara ekstrak daun lidah buaya dan daun sirih terhadap bakteri. Konsentrasi ekstrak daun lidah buaya dan daun sirih dari berbagai perlakuan menyebab kanvariasi pada panjang diameter daya hambat yang terbentuk. Kombinasi konsentrasi ekstrak lidah buaya 
dan sirih terhadap diameter daya hambat Streptococcus mutans dapat dilihat pada Gambar 1. Berdasarkan Gambar 1. Terdapat pengaruh nyata dan interaksi ekstrak daun lidah buaya dan sirih dalam menghambat pertumbuhan Streptococcus mutans sehingga menyebabkan perbedaaan besar diameter daya hambat. Interaksi yang terbentuk yaitu interaksi positif. Semakin tinggi konsentrasi ekstrak daun lidah buaya pada ekstrak daun sirih maka semakin besar daya hambat yang terbentuk, begitu juga sebaliknya.

Semakin besar konsentrasi kombinasi ekstrak yang diberikan maka semakin besar pula diameter daya hambat yang terbentuk terhadap kedua bakteri, karena semakin

\section{Daftar Pustaka}

1. Darby ML, Walsh MM (2010). Teori dan Praktek Kebersihan Gigi.

2. Chetrus V and Ion I.R (2013). "Dental Plaque - Classification, Formation, and Identification." Int. J. Med. Dentistry 3: 139-43.

3. Kreth J, Merritt J, Qi F (Agustus 2009). "Interaksibakteri dan inangstreptokokus oral" . Biologi DNA dan Sel . 28 (8): 397-403.

4. Harris NO, Christen AG 1995 Primary preventive dentistry. $4^{\text {th }}$ ed. Connectitut. Appleton and Lange;p. 342-8.

5. Furmawanti, I. 2002. Khasiat dan Manfaat Lidah Buaya Sitanaman Ajaib. Jakarta : Agromedia Pustaka, 8-10 www. library.um.ac.id/.../khasiat-dan-manfaat- banyak komponen bioaktif yang terkandung didalam ekstrak, bahwa efektivitas suatu zat antimikroba dipengaruhi oleh konsentrasi zat yang diberikan. Meningkatnya konsentrasi ekstrak mengakibatkan tingginya kandungan bahan aktif yang berfungsi sebagai antimikroba sehingga kemampuan untuk menghambat pertumbuhan mikroba juga semakin besar. Menghambat pertumbuhan bakteri $^{9}$ (Brooks et al. (2007).

Simpulan

Ada interaksi antara kombinasi konsentrasi dan jenis ekstrak dun lidah buaya dan daun sirih terhadap aktivitas anti bakteri Streptococcus mutans.

lidah-buaya-si-tanamanajaib-irnifurnawanth (28 September 2016).

6. Adi, Priyono Hari (2006). Hubungan Antara Pertumbuhan Ekonomi Daerah, Belanja Pembangunan Dan Pendapatan Asli Daerah (Studi pada Kabupaten dan Kota Se Jawa Bali), Symposium Nasional Akuntansi 9 Padang.

7. Suliantari, Jenie, B.S.L., Suhartono, M.T. \& Apriantono, A., 2008, Aktivitas Anti bakteri Ekstrak Sirh Hijau (Piper bittle L.) Terhadap Bakteri Patogen Pangan, Jurnal Teknologi dan Industri Pangan, 19 (1), 17.

8. Abdi, Redha "Flavonoid: Struktur, Sifat Antioksidatif Dan Peranannya Dalam Sistem Biologis" Jurnal, (Pontianak: Politeknik Negeri Pontianak, 2010) .

9. Brooks, GF., Carroll KC, Butel JS, Morse, and all (2013). Mikrobiologi Kedokteran Jawetz, Melnick, \& Adelberg. Ed. 25. Penerbit Buku Kedokteran EGC: Jakarta 
